\title{
Meðferð sykursýki af tegund 1 með insúlíndælu hjá fullorðnum á Íslandi
}

Katrín Ólöf Böðvarsdóttir læknir ${ }^{1}$ Thor Aspelund tölfræðingur², Arna Guðmundsdóttir læknir

\section{ÁGRIP}

Tilgangur: Markmið rannsóknarinnar var að kanna öryggi og árangur meðferðar með insúlíndælu á sykursýki af tegund 1 á Íslandi hjá einstaklingum 18 ára og eldri.

Efniviður og aðferðir: Skoðuð voru sjúkragögn 40 einstaklinga á aldrinum 19-57 ára sem fengið hafa insúlíndælu á Íslandi og verið með hana í sex mánuði eða lengur á tímabilinu 2004 til 2007. Athugað var hvaða áhrif meðferðin hafði á fylgikvilla meðferðar, HbA1c, pyngdarstuðul og magn insúlíns notað á dag samanborið við insúlínpennameðferð.

Niðurstöður: HbA1c lækkaði að meðaltali hjá bæði körlum og konum en ekki var um marktæka lækkun að ræða. Meðaltími dælumeðferðar var 23 mánuðir (staðalfrávik 12 mánuðir). Meðalupphafsgildi HbA1c hjá körlunum var 7,23 (95\% vikmörk 6,29-8,18) og 6,93 (95\% vikmörk 6,57-7,28) hjá konunum. Ekki varð marktæk breyting á pyngdarstuðli. Meðalpyngdarstuðull í upphafi var 25,5 (95\% vikmörk 23,6-27,3) hjá körlunum og 25,9 (95\% vikmörk 23,8-27,9) hjá konunum. Dagleg notkun insúlíns minnkaði marktækt hjá bæði körlum og konum. Minnkunin var að̃ meðaltali 11,3 einingar hjá körlum $(P=0,04)$ og 12,8 einingar hjá konum ( $P=0,0009)$. Á pessu fjögurra ára tímabili komu upp í rannsóknarhópnum sex tilvik af ketónblóðsýringu, fjögur tilfelli húðsýkingar og tvö sykurföll sem kröfðust læknisaðstoðar.

Ályktanir: Árangur meðferðar með insúlíndælum hér á landi er góður. Pessar niðurstöður staðfesta að meðferðin er örugg og stenst samanburð við önnur meðferðarform. Prátt fyrir að ekki hafi orðið marktæk lækkun á HbA1c var sýnt fram á að peir sem höfðu hæst HbA1c í upphafi náðu bestum árangri með meðferðinni og insúlínpörfin var minni.

${ }^{1}$ Landspítala, ${ }^{2}$ Háskóla Íslands Miðstöð í lýoheilsuvísindum

\section{Fyrirspurnir:}

Arna Guðmundsdóttir arnagu@landspitali.is

Barst: 31. maí 2010, sampykkt til birtingar: 16. mars 2011

Höfundar tiltaka hvorki styrki né hagsmunatengs.

\section{Inngangur}

Meðferð sykursýki með insúlíndælum hefur tíðkast í heiminum undanfarna prjá áratugi og hófst á Íslandi árið 2004. Upphaflega voru dælur hannaðar í rannsóknarskyni til að meta sambandið milli sykurstjórnunar og fylgikvilla sykursýkinnar en fljótlega kom í ljós að pær nýttust vel sem meðferðartæki við sykursýki af tegund $1 .{ }^{1}$ Snemma á níunda áratugnum var farið að notast við insúlíndælur sem meðferð við sykursýki af tegund 1 í nokkrum löndum. ${ }^{2}$

Rannsóknir hafa sýnt að pessi meðferð skilar góðum árangri fyrir stjórnun blóðsykurs, fækkar sykurföllum og bætir auk pess lífsgæði. ${ }^{3-6}$ Má í pví samhengi nefna að heilbrigðisstarfsfólk með sykursýki velur frekar meðhöndlun með dælu en hefðbundna meðferð með insúlínpennum eða sprautum. ${ }^{7}$

Sykursýki af tegund 1 er sjúkdómur sem getur haft alvarlega fylgikvilla í för með sér ef blóðsykri er ekki vel stjórnað. Rannsóknir hafa sýnt að öflug meðferð með premur eða fleiri insúlínsprautum á dag eða með insúlíndælu ásamt reglulegum blóðsykurmælingum, er betri meðferð til að hægja á eða fyrirbyggja fylgikvilla en pað sem áður var kallað hefðbundin meðferð og einkenndist af einni til tveimur sprautum af insúlíni á dag. ${ }^{8}$ Samkvæmt pekktri bandarískri rannsókn, svokallaðri Diabetes Control and Complications Trial (DCCT) rannsókn, ${ }^{8}$ er besta mögulega meðferðin í dag fjölsprautumeðferð eða insúlíndælumeðferð og má í raun segja að pessar tvær aðferðir séu nú orðin hefðbundin meðferð hér á landi.

Dælan (mynd 1) gefur ákveðinn grunnskammt insúlíns fyrir hverja klukkustund og er pannig hægt að stilla inn grunnskammt sem hentar hverjum og einum

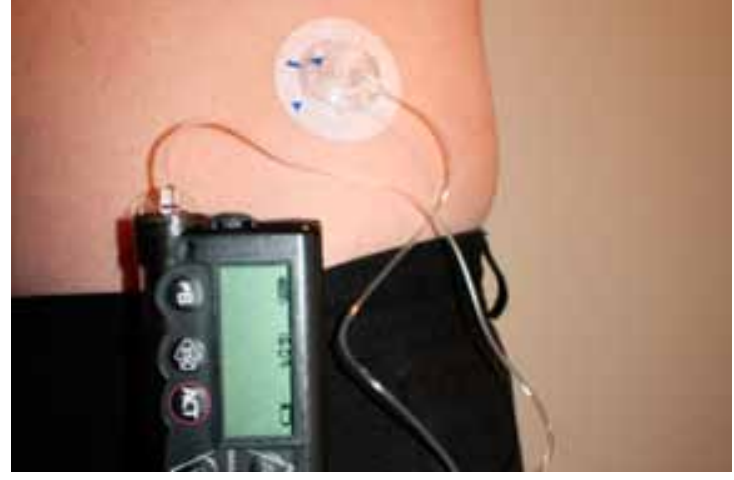

Mynd 1. Insúlíndæla í notkun. ${ }^{17}$ Meðferð með insúlíndælu felst í sídreypi fliótverkandi insúlíns undir húd. Dælan vegur um pað bil 100 g. Í henni er forðahylki með insúlíni sem dugar að meðaltali í prjá daga en pá parf að fylla á og skipta um hylkið og pað gerir sjúklingurinn sjálfur. Hylkið er tengt við granna plastslöngu og á enda hennar er fingert plaströr sem komið er fyrir undir húd með nál líkt og venflow nál, yfirleitt á kviði eða síðu. Mynd: Dórólfur Heiðar Porsteinsson.

fyrir hvert tímabil sólarhringsins. Á pennan hátt er auðveldara að mæta eðlilegum sveiflum í blóðsykri yfir sólarhringinn. Hægt er að draga tímabundið úr innrennslinu (temporary basal rate), sem kemur sér vel pegar fyrirhuguð er aukin líkamlega áreynsla eins og gönguferð eða líkamsrækt, eða aftengja dæluna alveg í eina til tvær klukkustundir. Раð dregur verulega úr líkum á sykurfalli. Pessi möguleiki til að stjórna grunnflæði insúlíns er eitt af pví sem talið hefur verið kostur dælunnar umfram fjölsprautumeðferð. Máltíðaskammta má gefa á prjá vegu (sjá myndir 2, 3 og 4). Rannsóknir hafa sýnt að með pví að gefa máltíðaskammta með tvískiptum skammti og langtímaskammti er hægt að lækka blóðsykur eftir máltíð umtalsvert. ${ }^{9}$

Meðferð með insúlíndælum hefur breiðst hratt út á undanförnum árum í nágrannalöndum okkar sem 


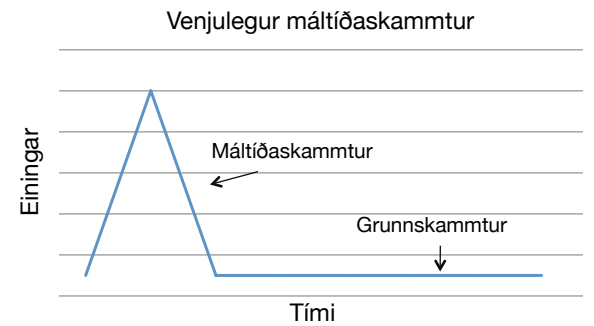

Mynd 2. Venjulegur máltíðaskammtur sem gefinn er allur í einu eins og gert er með insúlínpennum.

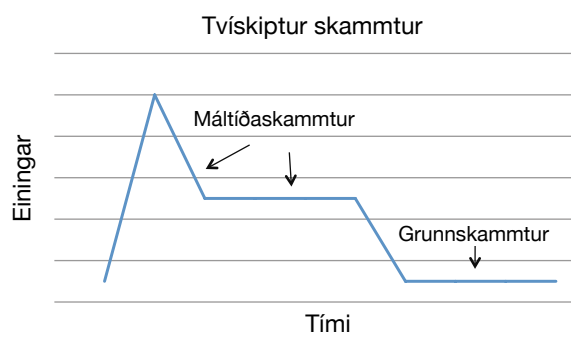

Mynd 3. Tvískiptur skammtur er gefinn pannig að ákveðinn hluti insúlínskammtsins er gefinn strax og afgangurinn svo gefinn á tímabili sem stillt er eftir poí hvað hentar hverju sinni, allt frá 30 mínútum upp íátta klukkustundir. Dessi aðferð reynist vel pegar máltíðin samanstendur til dæmis af pizzu par sem blóðsykurinn rýkur upp eftir máltíðina en er jafnframt lengi að ná eðlilegu gildi aftur.

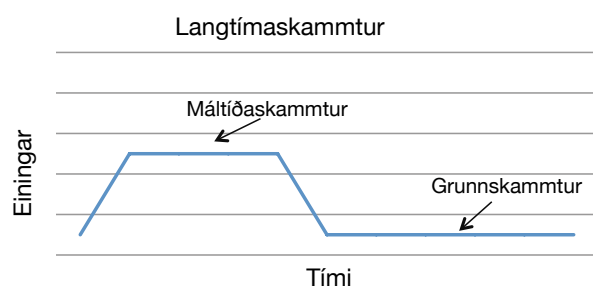

Mynd 4. Langtímaskammtur er allur gefinn á tímabili sem getur verið frá 30 mínútum upp íátta klukkustundir. og í Bandaríkjunum, ekki síst meðal barna og unglinga. Krafa samfélagsins í dag er sú að íslenskt heilbrigðiskerfi eigi að bjóða upp á bestu mögulegu meðferð gegn sjúkdómum og er sykursýki par engin undantekning. Par sem sýnt hafði verið fram á góðan árangur í meðferð á sykursýki með insúlíndælu ${ }^{3-5}$ var ákveðið að bjóða uppá pessa meðferð hér á landi. •að er mikilvægt að íslenskir læknar öðlist reynslu og hafi möguleika á að viðhalda peirri pekkingu sem peir hafa fengið erlendis á pessari tegund meðferðar og séu færir um að meðhöndla einstaklinga með dælu. Petta er ekki síst mikilvægt í ljósi pess að straumur ferðamanna til Íslands er stöðugt að aukast og hingað koma meðal annars ferðamenn með insúlíndælu. •að hefur verið sýnt fram á að pessi tegund meðferðar er hagkvæm í samanburði við önnur meðferðarform ${ }^{10,11}$ og á sparnaðartímum hefur pað mikið að segja við val á meðferð.

Meðferð með insúlíndælu hófst hér á landi í janúar 2004 og voru alls 103 einstaklingar komnir með dælu í janúar 2008. Par af var 71 eldri en 18 ára, eða 70\% dælunotenda, og 32 einstaklingar 18 ára eða yngri. petta er tæplega priðjungur barna með sykursýki af tegund 1 á Íslandi og um 10-14\% af fullorðnum. Í janúar 2010 voru 197 einstaklingar með insúlíndælu hér á landi en veruleg aukning varð á notkun pessa meðferðarforms á árunum 2007-2009, einkum á barnadeild.

Pær ábendingar og frábendingar sem stuðst hefur verið við hér á landi við uppsetningu insúlíndæla má sjá í töflu I.

\section{Efniviður og aðferðir}

Í rannsóknarhópinn völdust allir 18 ára og eldri með sykursýki af tegund 1 sem fengið hafa insúlíndælu á Íslandi og hafa verið með

Tafla I. Ábendingar og frábendingar fyrir uppsetningu insúlíndælu.

\begin{tabular}{l|l}
\hline Ábendingar fyrir uppsetningu dælu & Frábendingar fyrir uppsetningu dælu \\
\hline $\begin{array}{l}\text { 1. Ófullnægjandi stjórn prátt fyrir } \\
\text { góðan ásetning og tilraunir til } \\
\text { úrbóta }\end{array}$ & 1. Áhugaleysi \\
\hline $\begin{array}{l}\text { 2. Erfið stjórnun blóðsykurs að } \\
\text { næturlagi }\end{array}$ & 2. Geðræn eða félagsleg vandamál \\
\hline $\begin{array}{l}\text { 3. Óreglulegt hreyfimynstur - til } \\
\text { dæmis strangar ípróttaæfingar/ } \\
\text { keppni }\end{array}$ & 3. Léleg meðferðarheldni \\
\hline $\begin{array}{l}\text { 4. Óreglulegur vinnutími, til dæmis } \\
\text { vaktavinna }\end{array}$ & \\
\hline 5. Pungun & \\
\hline
\end{tabular}

dæluna í sex mánuði eða lengur. Tímabil rannsóknar var fjögur ár, frá ársbyrjun 2004 til loka árs 2007. Fyrsta árið, 2004, fengu átta fullorðnir einstaklingar dælu, 2005 12, 200613 og 2007 alls 12. Pátttakendur í rannsókninni voru 45 manns á aldrinum 19-74 ára, 25 konur og 20 karlar. Fimm voru útilokaðir í tölfræðiúrvinnslunni, par af voru fjórir sem ekki höfðu mætt í reglubundið eftirlit og ein kona sem var punguð meðan á rannsóknartímabili stóð.

Listar yfir dælunotendur voru fengnir frá Landspítala og fyrirtækinu Inter medica, sem flytur inn og pjónustar dælur af gerðinni MiniMed Paradigm sem hafa verið í notkun hér á landi. Upplýsingar voru fengnar úr sjúkraskrám á göngudeild sykursjúkra á Landspítala. Skráðar voru upplýsingar um $\mathrm{HbA1c}$ gildi, insúlínnotkun á sólarhring og líkamspyngdarstuðull (Body Mass Index, BMI) fyrir uppsetningu dælunnar og sex, 12 og 24 mánuðum eftir uppsetningu dælunnar. Einnig var skráður aldur við greiningu sykursýkinnar, hve lengi viðkomandi hafði haft sykursýki, kyn og upplýsingar um fylgikvilla sykursýkinnar. Skráðir voru fylgikvillar dælumeðferðar. Fylgikvillum dælu var skipt niður í prjá flokka: alvarlega ketónsýringu, alvarlegt sykurfall og sýkingu á stungustað. Voru ketónsýring og sykurföll metin eftir pví hvort viðkomandi purfti læknisaðstoð við leiðréttingu ástandsins, og sýkingarnar eftir pví hvort viðkomandi purfti sýklalyfjameðferð. Einnig var skráð hvort konur sem fengið höfðu dælur hefðu gengið með barn eftir uppsetningu hennar.

Tölfræðileg úrvinnsla: Línuleg líkön fyrir endurteknar mælingar (linear mixed effects models) voru notuð í tölfræðigreiningu til að meta upphafsstöðu og leitni í mæligildum yfir tíma. Leiðrétt var fyrir kyni, tíma frá greiningu sykursýki og aldri við greiningu. Slembipáttur (random effect) var notaður til að gera grein fyrir einstaklingsbundinni upphafsstöðu og leitni í mælingum. Forritið R, útgáfa 2.7.1 (www.r-project.org), var notað til útreikninga.

Öll tilskilin leyfi voru fengin frá Persónuvernd, lækningaforstjóra og siðanefnd Landspítala. Rannsóknarsniðið var afturskyggn hóprannsókn.

\section{Niðurstöður}

Tími frá greiningu sykursýkinnar par til dælumeðferð hófst hjá peim 40 einstaklingum sem tilheyra rannsóknarhópnum var 20 ár (miðgildi), millifjórðungsbil (interquartile range) var 11-25. Aldur við greiningu sykursýkinnar var 12 ár (miðgildi), millifjórðungsbil var 8-16 og meðalaldur rannsóknarhópsins 35,1 ár (staðalfrávik 11,1 ár). Dælumeðferðin á Íslandi hófst árið 2004 pannig að 


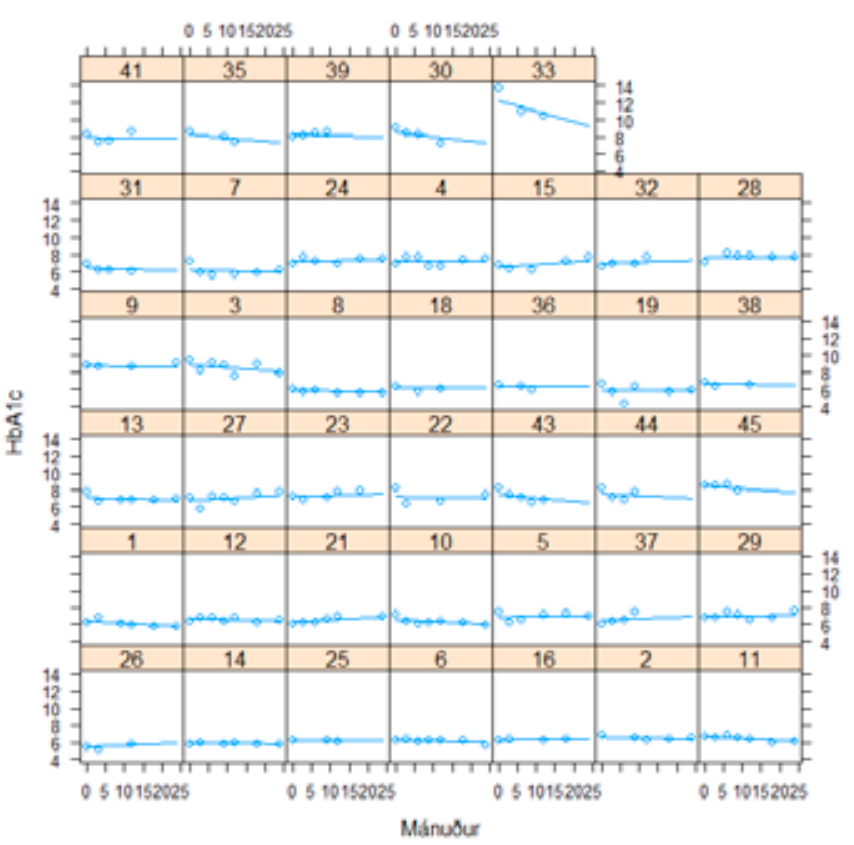

Mynd 5. HbA1c niðurstöður hjá pátttakendum rannsóknarinnar á móti tíma í mánuðum. Hver smámynd sýnir niðurstöður fyrir einn einstakling og eru peir táknaðir með númerum. HbA1c (y-ás) breyttist lítið yfir tímabil dælumeðferðarinnar (x-ás) hjá hverjum og einum. Sjá má að einstaklingur númer 33 lækkaði mest en hann var auk pess hæstur i upphafi meðferðar.

tíminn sem hver og einn hafði haft dæluna var mjög mislangur, frá sex mánuðum upp í fjögur ár. Meðaltíminn var 23 mánuðir (staðalfrávik 12 mánuðir).

Pegar fylgikvillar sykursýkinnar voru skoðaðir hjá hópnum kom í ljós að 22 einstaklingar voru með augnbotnabreytingar, sjö með nýrnakvilla (nephropathy) og prír með taugakvilla (neuropathy). Alls fengu 17 einstaklingar lyfjameðferð vegna háprýstings og 11 lyfjameðferð út af háu kólesteróli. Af öðrum sjálfsofnæmissjúkdómum voru sex með skjaldkirtilsvandamál og tveir með skort á B12. Sex konur í rannsóknarhópnum höfðu farið í gegnum meðgöngu með insúlíndælu.

HbA1c lækkaði að meðaltali hjá bæði körlum og konum en ekki var um marktæka lækkun að ræða (sjá mynd 5). Meðalupphafsgildi HbA1c hjá körlunum var 7,2\% (95\% vikmörk 6,29-8,18). Lækkun var að jafnaði 0,27 á ári $(\mathrm{p}=0,21)$. Peir sem voru með hátt HbA1c í upphafi lækkuðu hraðar $(\mathrm{p}=0,006)$. Meðalupphafsgildi hjá konum var 6,9\% (95\% vikmörk 6,57-7,28). Lækkun var að jafnaði 0,04 á ári $(\mathrm{p}=0,63$ ). Meðalgildi HbA1c var 6,9\% (vikmörk 6,6-7,3) í lok rannsóknar hjá peim 22 einstaklingum sem höfðu haft dæluna lengst eða í 24 mánuði.

Ekki varð marktæk breyting á pyngdarstuðli (mynd 6). Meðallíkamspyngdarstuðull í byrjun var 25,5 (95\% vikmörk 23,6$27,3)$ hjá körlunum og 25,9 (95\% vikmörk 23,8-27,9) hjá konunum. Aðeins lágu fyrir upplýsingar um pyngd hjá 29 af 40 einstaklingum.

Dagleg notkun insúlíns minnkaði marktækt bæði hjá körlum og konum (mynd 7). Minnkunin var að meðaltali 11,3 einingar hjá

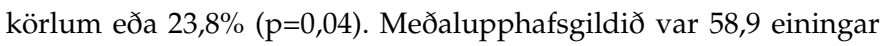
(95\% vikmörk 52,3-64,8) og eftir tvö ár var meðalgildið 47,3 einingar (95\% vikmörk 38,1-56,5). Minnkunin var 12,8 einingar hjá konum ( $\mathrm{p}=0,0009)$ eða $34 \%$. Meðalupphafsgildið var 50,4 einingar $(95 \%$ vikmörk 44,5-56,2) og eftir tvö ár var meðalgildið 37,6 einingar (95\% vikmörk 32,3-42,8). Ekki var marktækur munur á lækkun

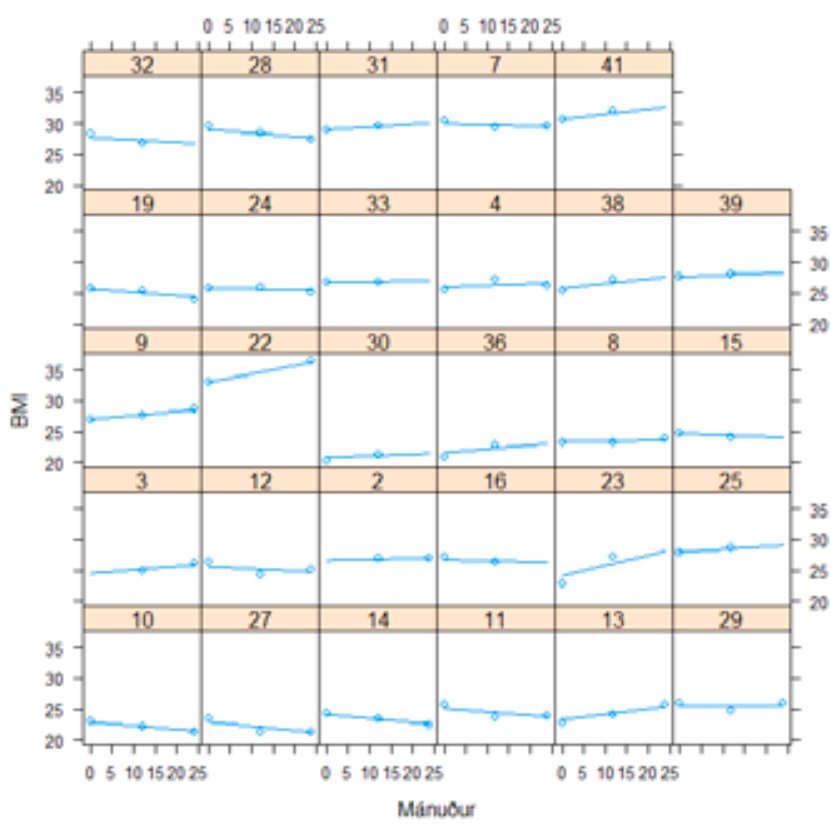

Mynd 6. Líkamspyngdarstuðull hjá pátttakendum rannsóknarinnar á móti tíma í mánuðum. Hver smámynd sýnir niðurstöđur fyrir einn einstakling og eru peir táknaðir með númerum. Líkamspyngdarstuðull hjá 29 einstaklingum (körlum og konum) var að mestu óbreyttur.

insúlínmagns milli karla og kvenna. Karlar voru hærri í byrjun og notuðu 8,2 einingum meira á sólarhring en konur (staðalskekkja $3,6 \mathrm{p}=0,02$ ). Insúlín við upphaf notkunar var breytilegt eftir kyni, tíma frá greiningu og aldri við greiningu. Breyting í tíma eftir að notkun dælu hófst var ápekk hjá öllum hópnum eins og mynd 7 sýnir: einstaklingsbundnu aðhvarfslínurnar eru nærri pví samsíða. Tilgátunni um samsíða aðhvarfslínur var ekki hafnað $(\mathrm{P}=0,15)$. Breytingin var að jafnaði lækkun um 0,48 (0,26-0,71) einingar á mánuði yfir 24 mánaða tímabil.

Á pessu fjögurra ára tímabili komu sex tilvik af ketónblóðsýringu upp í rannsóknarhópnum (0,07 tilfelli á sjúklingarári), fjögur tilfelli húðsýkingar (0,05 tilfelli á sjúklingaári) og tvö sykurföll (0,02 tilfelli á sjúklingaári) par sem læknisaðstoðar var pörf. Meðferðarlengd með dælu áður en fylgikvillar komu upp (meðaltöl í mánuðum) voru 13,8 mánuðir (min 2, max 23) fyrir ketónsýringu, 21,5 mánuður (min 2, max 40) fyrir sýkingu og fimm mánuðir (min 1, max 9) fyrir blóðsykurfall.

\section{Umræður}

Prátt fyrir að ekki hafi orðið marktæk lækkun á HbA1c líkt og sýnt hefur verið fram á í mörgum öðrum rannsóknum, ${ }^{3-5,12}$ var í pessari rannsókn sýnt fram á að peir sem höfðu hæst HbA1c í upphafi náðu bestum árangri með meðferðinni en petta hefur einnig verið raunin í erlendum rannsóknum. ${ }^{13}$ Рað að ekki var sýnt fram á marktæka lækkun á $\mathrm{HbA1c}$ í okkar rannsókn gæti skýrst af sjúklingavali í upphafi meðferðarinnar. Ábendingar og frábendingar fyrir uppsetningu dælunnar (sjá töflu I) eru í grundvallaratriðum pær sömu hér á landi og National Institute for Clinical Excellence (NICE) hefur notað. ${ }^{11}$ Undantekning er að NICE gerir kröfu um að sjúklingar verði að hafa $\mathrm{HbA1c}$ gildi 8,5\% eða hærra. Fyrstu prjú árin var fyrst og fremst valið eftir áhuga sjúklinga á meðferðinni 


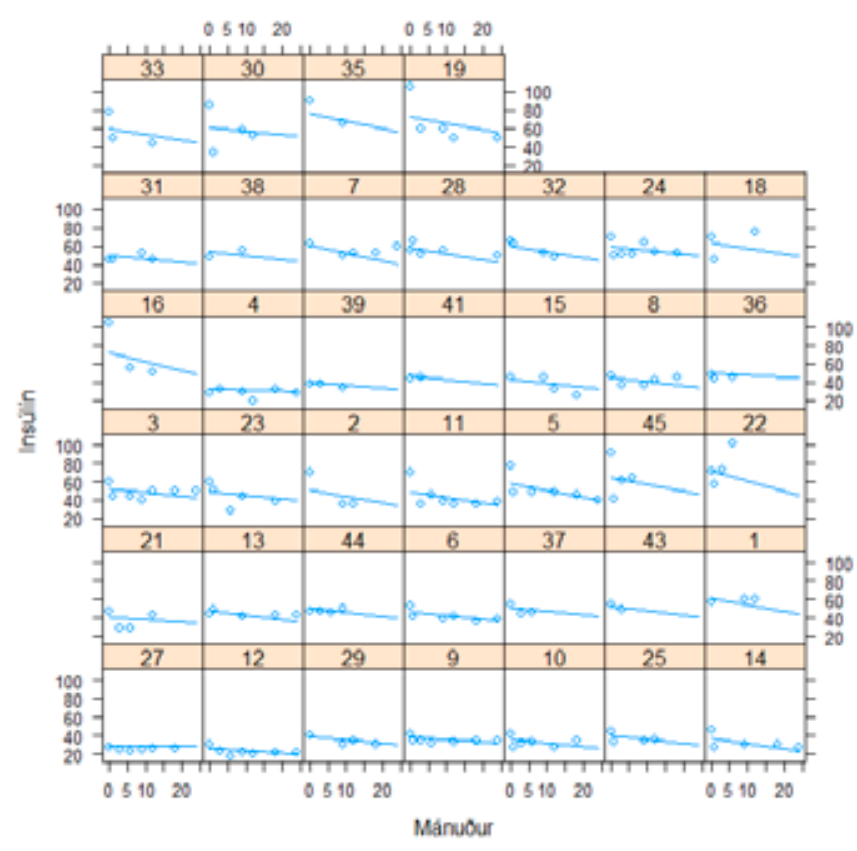

Mynd 7. Insúlíneiningar á móti tíma í mánuðum frá poí að notkun dælu hefst, fyrir hvern einstakling rannsóknarinnar sem átti insúlínskammta skráda í að minnsta kosti tö̈ skipti. Einstaklingsbundnar aðhvarfslínur sýna leitnina í gildunum.

og reynt að forðast pá sem áttu í verulegum erfiðleikum með blóðsykurstjórn eða voru með lélega meðferðarheldni. Pessi leið var meðal annars valin meðan starfsfólk var að öðlast reynslu og pekkingu á pessu nýja meðferðarformi. Sýnt hefur verið fram á að með pví að rýmka ábendingar fyrir uppsetningu dælu má ná enn betri meðferðarárangri, pað er að peir sem eru í vandræðum með háan blóðsykur og tíð blóðsykurföll ná mun betri árangri með dælumeðferð en fjölsprautumeðferð. ${ }^{14}$ Ef niðurstöður okkar eru skoðaðar má segja að petta eigi einnig við hér á landi. Við sjáum að peir sem voru með slæma sykurstjórn fyrir dæluuppsetningu með $\mathrm{HbA} 1 \mathrm{c}>9 \%$ ná bestum árangri. Petta er mikill kostur par sem lægra $\mathrm{HbA1c}$ leiðir af sér færri fylgikvilla og ekki eins alvarlega og verður par af leiðandi kostnaðarlega hagkvæmara. Ekki er útilokað að bætt sykurstjórnun og lækkun á insúlínskammti sem oft sést í upphafi meðferðar með insúlíndælu geti að einhverju leyti skýrst af péttara eftirliti fyrst um sinn og aukinni fræðslu um sykursýki og mataræði sem dælusjúklingar fá við uppsetningu tækisins.

Ekki varð marktæk breyting á pyngdarstuðli rannsóknarhópsins. Petta er í raun jákvæð niðurstaða par sem íslenska pjóðin í heild hefur pyngst á undanförnum árum og samkvæmt nýlegri íslenskri rannsókn var sýnt fram á að meðaltalspyngdarstuðull fyrir íslenska karlmenn á aldrinum 25-34 ára er 26,2 og 27,6 fyrir karlmenn á aldrinum 35-44 ára. ${ }^{15}$ Meðaltalspyngdarstuðull fyrir karlmenn í okkar rannsókn var 25,5. Niðurstöður varðandi líkamspyngd eru misvísandi í erlendum rannsóknum. Sumar peirra hafa sýnt pyngdaraukningu meðal dælunotenda sem notað hafa minna insúlínmagn en pá hefur jafnframt sést marktæk lækkun á HbA1c., ${ }^{3,4}$

Marktæk lækkun varð á insúlínnotkun á sólarhring hjá hópnum eftir uppsetningu dælunnar. Insúlínnotkunin lækkaði um 23,8\% hjá körlunum og 34,0\% hjá konunum.

Margar aðrar rannsóknir hafa sýnt fram á að insúlínnotkun er töluvert minni í dælumeðferð en fjölsprautumeðferð. ${ }^{3,4,12-14}$ Petta lækkar einnig kostnað.

Íslenskir dælunotendur eru almennt ánægðir með meðferðina og enginn hefur kosið að skipta yfir í pennameðferð að nýju eftir að hafa notað dælu í nokkra daga. Erlendum rannsóknum ber saman um að lífsgæði sykursjúkra aukast með dælumeðferð í samanburði við sprautumeðferð og var petta pví ekki kannað sérstaklega í okkar rannsókn. ${ }^{4-6}$

Ekki var sýnt fram á að tíðni bráðra fylgikvilla insúlíndælumeðferðar (blóðsykurfalls/ketónsýringar/húðsýkingar) sé hærri hér á landi en annars staðar. Í okkar rannsókn fengu 12,5\% hópsins ketónsýringu eða 0,07 tilfelli á sjúklingaári. Aðrar rannsóknir hafa sýnt tíðni upp á 0,01-0,06 tilfelli á sjúklingaári ${ }^{4,5}$ eftir uppsetningu dælunnar. Í rannsóknarhópnum voru fjórir einstaklingar sem fengu húðsýkingu er krafðist sýklalyfjameðferðar og eru pað um pað bil 10\% hópsins eða 0,05 tilfelli á sjúklingaári. Petta er svipað pví sem sést hefur annars staðar. ${ }^{5}$ Hvað varðar blóðsykurfall voru aðeins tveir úr hópnum sem fengu alvarlegt blóðsykurfall eða 0,02 tilfelli/ sjúklingaár. Eru petta um 5\% hópsins. Petta eru svipaðar tíðnitölur og aðrar rannsóknir hafa sýnt., ${ }^{4,5}$ Eftir pví sem menn leitast við að lækka HbA1c gildi eykst samhliða hættan á alvarlegum blóðsykurföllum. ${ }^{8}$ Rannsóknir hafa sýnt að dælumeðferð lækkar HbA1c án pess að auka tíðni blóðsykurfalla. ${ }^{4,5,16}$ Petta skapar aukið öryggi fyrir hinn sykursjúka, hann nær betri meðferðarárangri en minni líkur eru á hættulegri aukaverkunum meðferðarinnar eins og blóðsykurfalli. Í einni rannsókn var sýnt fram á að peir sem áttu í mestum vandræðum með blóðsykurföll fyrir uppsetningu dælu náđu bestum árangri í að minnka tíðni peirra eftir uppsetningu. ${ }^{16}$ Hvað varðar fylgikvilla dælunnar sjálfrar er mjög mikilvægt að sá sem er meðhöndlaður með dælumeðferð sé vel upplýstur um mögulega fylgikvilla og hvernig best sé að bregðast við peim. Раð er besta forvörnin gegn fylgikvillunum.

Pó að beinn kostnaður við uppsetningu insúlíndælu sé sannarlega mun meiri en við upphaf fjölsprautumeðferðar hefur verið sýnt fram á að til lengri tíma litið er dælumeðferð hagkvæmari en fjölsprautumeðferð. ${ }^{11,12}$

Styrkleiki rannsóknarinnar er að sýna fram á að ekki hafi orðið aukning á alvarlegum vandamálum í upphafi meðferðar með insúlíndælum. Pegar notkun á insúlíndælum jókst erlendis, fyrir 10-15 árum, var helsta áhyggjuefni meðferðaraðila að eingöngu var stuðst við skammvirk insúlín og pví ljóst að ef tækjabúnaður bilaði gæti líkaminn orðið súr á skömmum tíma og stefnt viðkomandi í hættu. Tilfellum ketónsýrings hefur hins vegar fækkað, sem kann að skýrast af pví að dælurnar eru orðnar fullkomnari og með betri viðvörunarbúnaði ef insúlínflæði rofnar. ${ }^{5}$

Veikleiki rannsóknarinnar er að hafa ekki fleiri mælingar á HbA1c og líkamspyngdarstuðli fyrir breytingu á meðferð. Einnig hefði verið áhugavert að leggja fyrir spurningalista varðandi lífsgæði en til pess hefði rannsóknin purft að vera framskyggn.

Árangur meðferðar með insúlíndælum hjá fullorðnum á Íslandi er góður. Pessar niðurstöður staðfesta að meðferðin er örugg og stenst fyllilega samanburð við önnur meðferðarform. 


\section{Heimildir}

1. Pickup JC, Keen H, Parsons JA, Aolberti KGMM, Rowe AS. Continuous subcutaneous insulin infusion: an approach to achieving normoglycaemia. BMJ 1978; 1: 204-

2. Mecklenburg RS, Benson JW, Becker NM, et al. Clinical use of the insulin infusion pump in 100 patients with type 1 diabetes. N Engl J Med 1982; 307: 513-8.

3. Weissberg-Benchell I, Antisdel-Lomaglio J, Seshadri R Insulin pump therapy: a meta-analysis. Diabetes Care 2003; 26:1079-87

4. Giménez M, Conget I, Jansá M, Vidal M, Chiganer G, Levy I. Efficiacy of cotinuous subcutaneous insulin infusion in Type 1 diabetes: a 2-year perspective using the established criteria for funding from a National Health Service. Diabet Med 2007; 24: 1419-142.

5. Linkeschova R, Raoul M, Bott U, Berger M, Spraul M Less severe hypoglycaemia, better metabolic control, and improved quality of life in Type 1 diabetes mellitus with continuous subcutaneous insulin infusion (CSII) therapy; an observational study of 100 consecutive patients followed for a mean of 2 years. Diabet Med 2002; 19: 746 51.

6. The equality1 study group. Quality of life and treatment satisfaction in adults with Type 1 diabetes: a comparison between continous subcutaneous insulin infusion and multiple daily injections. Diabet Med 2008; 25: 213-20.
7. Graff MR, Rubin RR, Walker EA: How diabetes specialists treat their own diabetes: findings from a study of the AADE and ADA membership. Diabetes Educ 2000; 26: 460-67.

8. The DCCT Research Group. The effect of intensive treatment of diabetes on the development and progression of long-term complications in insulin-dependent diabetes mellitus. N Engl J Med 1993; 329: 977-86.

9. Chase HP, Saib SZ, MacKenzie T, Hansaen MM, Garg SK Post-prandial glucose excursions following four methods of bolus insulin administration in subjects with type 1 diabetes. Diabet med 2002; 19: 317-21.

10. NICE technology appraisal guidance 151, continous subcutaneous insulin infusion for the treatment og diabetes mellitus. quidance.nice.org.uk/TA151 apríl 2011.

11. Roze S, Valentine WJ, Zakrezwska KE, Palmer AJ. Healtheconomic comparison of continuous subcutaneous insulin infusion with multiple daily injection for the treatment of type 1 diabetes in the UK. Diabet Med 2004; 22; 1239-45.

12. Pickup J, Matock M, Kerry S. Glycaemic control with continous subcutaneous insulin infusion compared with intensive insulin injections in patients with type 1 diabetes: meta-analysis of randomised controlled trials. BMJ 2002; 324: 1-6.
13. Retnakaran R, Hochman J, DeVries JH, et al. Continous subcutaneous insulin infusion versus multiple daily injections. Diabetes care 2004; 27: 2590-6.

14. Rodrigues IAS, Reid HA, Ismail K, Amiel SA. Indication and efficiacy of continous subcutaneous insulin infusion (CSII) thearpy in type 1 diabetes mellitus: a clinical audit in a specialist service. Diabet Med 2005; 22: 842-9.

15. Bórsson B, Aspelund T, Harris TB, Launer LJ, Guðnason V. Próun holdafars og sykursýki í 40 ár á Íslandi. Læknablaðið 2009; 95: 259-66.

16. Pickup JC, Sutton AJ. Severe hypoglycaemia and glycaemic control in Type 1 diabetes: meta-analysis of multiple daily insulin injections compared with continuous subcutaneous insulin infusion. Diabet Med 2008; $25: 765-74$.

\section{ENGLISH SUMMARY}

\section{Treatment of type 1 diabetes with continuous subcutaneous insulin infusion (CSII) in adults in Iceland} Bodvarsdottir KO, Aspelund T, Gudmundsdottir A

Objective: The goal of the study was to evaluate the effect and safety of CSII treatment in individuals 18 years and older with type 1 diabetes mellitus in Iceland.

Methods: The research is retrospective. We gathered information from patient data of 40 individuals, age $19-57$ years who had been treated with CSII in Iceland for 6 months or longer during the period January 2004 until December 2007 . We looked at the effect of the treatment on treatment complications, $\mathrm{HbA1c}$, body mass index (BMI) and insulin requirements compared with multiple daily injections (MDI).

Results: $\mathrm{HbA} 1 \mathrm{c}$ was lower on CSII but the difference was not significant. Mean initial HbA1c was 7.23 (95\% confidence limits 6.29-8.18) for men and 6.93 (95\% confidence limits 6.57-7.28) for women. The change in BMI was not significant. Mean initial BMI for men was 25.5 (95\% confidence limits $23.6-27.3$ ) and 25.9 (95\% confidence limits 23.8-27.9) for women. Insulin requirements were significantly lower at the end of the study for both men and women. Insulin requirements decreased by mean 11.3 units for men $(P=0.04)$ and 12.8 units for women $(P=0.0009)$. There where six episodes of ketoacidosis, four of skin infections and two hypoglycemias that needed doctors attention while using CSII treatment.

Conclusion: The experience of CSII treatment in Iceland is good. These results confirm that this treatment is safe and as effective as other treatment forms. Even tough the difference in $\mathrm{HbA} 1 \mathrm{c}$ was not significant the result showed that those who had the highest HbA1c at the beginning of CSII treatment did get the best result with the pump and the insulin dosage was lower with CSII than with MDI.

Key words: Diabetes, Continuous subcutaneous insulin infusion, HbA1c, Insulin dose, hypoglycemia.

Correspondence: Arna Guðrmundsdóttir, arnagu@landspitali.is 